\title{
Development an honesty and discipline assessment instrument in the integrated thematic learning at elementary school
}

\author{
Ari Setiawan ${ }^{1 *}$, Syarief Fajarudin ${ }^{2}$, Dinar Westri Andini ${ }^{3}$ \\ ${ }^{1}$ Universitas Sarjanawiyata Tamansiswa. Jalan Kusumanegara No.157, Muja Muju, Umbulharjo, \\ Yogyakarta, 55165, Indonesia \\ ${ }^{2}$ Universitas Negeri Yogyakarta. Jalan Colombo No 1, Karangmalang, Yogyakarta, 55281, Indonesia \\ ${ }^{3}$ Department of Elementary School Teacher Education, Universitas Sarjanawiyata Tamansiswa. \\ Jalan Batikan UH-III/1043 Yogyakarta, 55167, Indonesia \\ * Corresponding Author. E-mail: ari.setiawan@ustjogja.ac.id \\ Received: 16 January 2019; Revised: 29 January 2019; Accepted: 30 January 2019
}

\begin{abstract}
Honest and discipline as learning outcomes need to be assessed. Many teachers have difficulty developing honesty and discipline assessments. The lack of honest and discipline assessment instruments require special attention in development. The purposes of this developmental research were to find out: (1) honest and discipline instrument indicators; (2) content validity of the instrument; (3) construct validity of the instrument; (4) instrument reliability and (5) instrument application for assessment. The research method used the development of affective instruments. The research subjects were 140 students of grade IV and V on the elementary school. The instrument used a peer-assessment model with a summative rating scale. Data analysis technique used content validity with Aiken index; construct validity with Exploratory Factor Analysis (EFA); reliability with Cronbach; and application of instrument with descriptive quantitative. The results of the study were indicators of honest assessment instruments and discipline of the peer-assessment model, consisted of 4 , honest: convey the true information and do the examination independently. Discipline: come to school on time and obey the rules of the school. The content validity of the developed assessment instruments based on the theory had fulfilled and included in the high category. The construct validity for the developed instrument had fulfilled; means, all items were valid. Reliability of the developed instrument had met the requirements; means, the instruments were reliable. The developed instruments can be used for assessment and proved by the use of instruments for honest and disciplined assessment of elementary school students. Keyword: instrument development, honesty and discipline, elementary school
\end{abstract}

How to Cite: Setiawan, A., Fajaruddin, S., \& Andini, D. (2019). Development an honesty and discipline assessment instrument in the integrated thematic learning at elementary school. Jurnal Prima Edukasia, 7(1), 919. doi:https://doi.org/10.21831/jpe.v7i1.23117

doi

https://doi.org/10.21831/jpe.v7i1.23117

\section{Introduction}

Learning process in the elementary school degree has long been using the thematic approach. In relation to the statement, an integrated thematic learning approach refers to the learning process that has been implemented in the framework of 2013 Curriculum (M. Handayani, 2018, p.167; Utari, Degeng \& Akbar, 2016). A thematic learning process itself might be defined as a learning process that involves several subject matters in order to provide meaningful experience for the students by associating one theme to another (Ain \& Rahutmi, 2018; M. Handayani, 2018; Karli, 2016; MIllah \& Syah, 2017;
Mujimin, 2006; Soero, Sulistyo \& Hayat, 2014). Therefore, the students will understand the concept that they learn through immediate experience and association to other concepts that they have understood. In comparison to the conventional learning approach, the thematic learning approach will invite more active engagement of the students both physically and mentally in the teaching-learning activities within the classroom (Karli, 2016). The reason is that the thematic learning process demands the students to be active both in terms of cognition and in terms of learning materials recalling the fact that the teaching materials are more realistic. 
Jurnal Prima Edukasia, 7 (1), 2019 -10

Ari Setiawan, Syarief Fajarudin, Dinar Westri Andini

On the other hand, Meinbach, Rothlein \& Fredericks (2000) argue that thematic learning is a multidisciplinary (involving multiple subject matters) and multi-componential (involving several aspects such as skills, behaviours and knowledge) learning process and a thematic learning is performed in accordance to the interest, the capacity and the needs of the students. In addition, a thematic learning appreciates each talent and each attitude that have been developed by the students. As a result, it is expected that through thematic learning the interest, the talent, the social attitude and the behaviours of the students might be well-developed (Widyaningrum, 2012). Furthermore, a thematic learning also provides bigger portion of interaction with social environment for the students (Salamah, 2017).

The elementary school students who have started their interaction with the social environment will start internalizing the social attitude (Handayani, 2018). Social attitude is a tendency that has been mastered in order to evaluate social matters through certain manners. Social attitude is an important part within the development of a child because social attitude shapes the perception of the child toward the social environment, which has concrete influence on the behaviour of the child (Crano \& Prislin, 2008).

With regards to social attitude, the changes in and the development of the social attitude among the elementary school students have been concerning. The elementary school students nowadays tend to be less discipline, "lack" of responsibility and low in honesty (based on the observation on January 2018). Such situation is completely in contradiction to the ideal condition within the development of social attitude among the elementary school students. According to Ekowarni (2009, pp.10-14), attitude development has strong association to the social conditions that might be habituated among the elementary school students such as piety, affection, cooperation, discipline, humility, emotion control, tolerance, independence, honesty, self-confidence, thrifty, persistence, positive-thinking, fairness, peace respect, creativity, citizenship, responsibility and sincerity.

The attitude of honesty and discipline has been the part of social attitude (Setiawan \& Suardiman, 2018). The attitude of honesty and discipline as part of the core of the education that aims at generating the generation of moral has not been completely assessed yet due to the limitation on the assessment instrument and the teacher capacity especially in the assessment process. The teachers tend to complete the teaching period without viewing the significance of performing an accurate assessment. The results of a study by Stiggins (2005) show that a teacher actually should complete two-third until half of the available teaching period by being involved in assessment activities. Through the assessment activities, a teacher will continually make decisions with regards to the interaction with their students and the decisions will be based partly on the information that they have gathered about the students from the assessment. Unfortunately, in the practice the teachers do not spare their time for the honesty and discipline assessment of the students.

According to Koelhoffer (2009), honesty might be defined as proclaiming truth, not telling a lie, not cheating and not deceiving. Honesty is manifested through words and actions that describe the actual condition without any deceit and through straightforward information with brief, spontaneous and natural manner. In sum, honesty might be defined as being trustworthy due to the words and actions that go in accordance to the truth. Departing from the statement, honesty might refer to the perception of being trustworthy in words, actions and jobs. Among the elementary school students, honesty is an aspect that should be internalized since the beginning. The root of honesty, namely honest, itself is an adjective that bears several importance namely: (1) not telling a lie (being straightforward); (2) not being deceitful (for example: attending to the governing regulations during a discussion); and sincere. Honesty thus is an attitude of not telling a lie and having a straightforward heart that an individual has internalized as the reflection of his or her life values.

The components of honesty that has numerous indicators might be involved into the design of an accurate assessment. These indicators might be adjusted to the level of development among the elementary school students. In addition, these indicators have strong association to the daily life and the daily teaching-learning activities of the students. Then, the indicators of honesty that will be involved in the study are: (1) the students complete the test independently; and (2) the students deliver information in a straightforward manner. Raka et al. (2011, p.113) state that discipline refers to performing kindness based on the willingness and the awareness of an individual instead of request or supervision. In this regard, the most important aspect that should 
be developed is self-discipline. Self-discipline refers to the attitude of discipline that appears from the self-awareness, the self-belied and the self-understanding instead of fear.

The development of discipline refers to the opinion by Nucci \& Narvaez (2008, p.197), who explain that the development of discipline might assist the teachers in developing the needs of trustworthy relationship and might also assist all students to learn and develop both academically and morally. The development of discipline that a teacher has pursued might shape the students into a personality of discipline and improve students' academic achievement altogether in the same time. The students who internalize the characteristics of discipline in their daily life will certainly show the characteristics of discipline on the learning process within both in their classroom and their house. Consequently, the characteristics of discipline will indirectly influence the improvement of the students' academic achievement in the school. Furthermore, Lickona (2004, p.164) states that discipline does not refer to any control on the group of students but instead refers to the character education with discipline as the main direction. Referring to multiple opinions that have been elaborated previously, it might be concluded that student's discipline refers to the act of order and obedience toward numerous requirements and regulations in the school. The indicators of discipline among the elementary school students are namely: (1) the students always come on time; (2) the students obey the school regulations; (3) the students use things in accordance to their function; (4) the students pick up and return things from and into their place; (5) the students try to obey the regulations that have been agreed; and (6) the students wait for their turn in order.

The dimensions of discipline with their indicators will ease the assessment process since these indicators might be adjusted to the level of the development among the elementary school students. In addition, these indicators are strongly associated to the students' teaching-learning activities and daily life. Then, the indicators that will be investigated within the study are the students come on time to school/classroom and the students obey the school regulation.

The limited instrument for the assessment of honesty and discipline becomes the main reason behind the conduct of the study. With regards to the statement, the final objective of conducting the study is to generate an assessment instrument of honesty and discpline in the form of peer-assessment. Peer-Assessment (PA) is an activity of assessment that involves the students and their peers during the learning processs under the framework of providing constructive feedback (Karami \& Rezai, 2015; Setiawan \& Suardiman, 2018; Sriyati, Permana, Arini \& Purnamasari, 2016; Wanner \& Palmer, 2018). As an alternative, PA might also be described as an assessment model that entails the students' decision with regards to the assignment/task of their peers during the cooperation in their group.

Basically, several definitions of PA provided by the experts similarly display the involvement of other students in the assessment process. Peer Assesssment is a form of assessment that aims at eliciting feedback information from the peers in addition to eliciting feedback information from the teachers (Clarke, 2005; Wijayanto \& Mundilarto, 2015). Furthermore, Wijayanti \& Mundilarto (2015) define that Peer Assessment is a process of involving students to provide peer feedback by means of marking activities. Black et al. (Clarke, 2005) asserts that Peer Assessment might be effective feedback during the teaching-learning process since the students have more freedom to mutually provide and receive criticisms from one to another under their daily language. The students thus will be more excited in their learning process if they have feedback from both their teachers and their peers. Ellington, Earl \& Cowan (1997) assert that the involvement of students in Peer Assessment might be performed by mutually assessing each other. One of the activities that might be done in relation to the statement is observing the behaviours of the students' peers. The use of PA serves as the effort of improving the learning process quality, especially in involving the students into the assessment process, so that the students' social interaction will increase, the students' trust toward their peers will also increase and the teachers are assisted in eliciting the individual feedback of the students. Based on the above elaboration, it might be concluded that PA might serve as the basis of summative assessment in addition to serving as the basis of formative assessment. In other words, the information about the students' capacity that have been gathered during the learning process might be a matter of reference for the achievement of the students' learning results. In addition, it has been asserted by Dochy et al. (1999) that PA might serve as the basis of both formative and summative assessment and might 
Jurnal Prima Edukasia, 7 (1), 2019 -12

Ari Setiawan, Syarief Fajarudin, Dinar Westri Andini

even design a wider assessment scheme in combination with self-assessment.

Within the conduct of the study, the main focus is the development of assessment instrument the students' social attitude, namely honesty and discipline, for Grade IV and V of elementary schools. The instrument that has been developed is expected to assist the elementary school teachers to assess the students' honesty and discipline in the school environment appropriately. Both components are strengthened by the Core Competence II in 2013 Curriculum. In other words, the social attitude which assessment instrument will be developed only consists of honesty and discipline.

\section{Method}

The study aimed at developing an assessment instrument of elementary school students' honesty and discipline within the integrated thematic learning process. Then, the social attitude assessment instrument that had been developed was a non-test instrument. The development of the social attitude assessment instrument was based on the components of honesty and discipline. On the other hand, the form of the instrument that had been developed was the Peer Assessment (PA) questionnaire.

The model for the development of the assessment instrument referred to the procedures that had been suggested by McCoach, Gable \& Madura (2013, pp.277-283) with modification. The assessment instrument was developed based on the social attitude that might be found on the components of honesty and discipline. The matters of consideration within the development of the assessment instrument were theoretical review, components of indicator establishment, measurement scale and school needs. Then, as having been stated in the previous paragraph, the instrument that had been developed was the Peer Assessment (PA). The model of development had been selected based on the results of the theoretical review, the facts in the fueld and the effectiveness of use. In the same time, within the conduct of the study the researcher also elied on the data that had been gathered from both the experts and the teachers in terms of instrument quality. The data from both the experts and the teachers were provided in the form of assessment. The sequence in the conduct of the study might be consulted in Figure 1.

The sample that had been selected for the conduct of the study was the students from Grade IV and Grade V of the elementary schools that had implemented the integrated thematic learning approach. The students who had been the sample of the study were gathered from three elementary schools and the total number of the respondent was 140 people.

Data gathering method and data gathering instrument were very significant in defining the data that had been gathered. The main data in the research and development effort were the quantitative data. The quantitative data were based on the provision of scores that had been assigned on the instrument that had been developed. Then, the supporting data in the research and development effort were the qiualitative data. In general, within the study the qualitative data referred to the data that had been attained from the discussions, the instrument readability test and the expert judgment. Then, the qualitative data were used in developing the constructs of social attitude assessment by viewing both the teachers' readability and the instrument's validity from the aspect of expert judgment. On the other hand, the quantitative data were used in viewing the students' readability, the construct validity, and the construct reliability of the instrument that had been developed. The quantitative data were gathered from the instrument that had been developed namely Peer-Assessment (PA) questionnaire.

The data analysis in the study was divided into two main stages. The first main stage was the analysis toward the assessment instrument that had been developed from the aspect of validity and reliability after the testing took place. The second main stage was the analysis toward the results of instrument implementation in the assessment of honesty and discipline.

The validity of an item should be able to explain the measurement or the assessment along with the aspects under measurement or assessment. The agreement among the experts within the expert judgment toward the indicators and the items of the social attitude honesty and discipline heavily defined the content validity because the instrument that had been developed was believed to measure the honesty and the discipline. In order to identify the agreement within the expert judgment, the index of item validity that had been proposed by Aiken (Kumaidi, 2014) should be employed. According to Retnawati (2016, p.31), the results of Aiken agreement index might be categorized into 3 namely low validity (less than 0.40 ), moderate validity (between 0.41 and 0.80 ) and high validity (higher than 0.80 ). 
Jurnal Prima Edukasia, 7 (1), 2019 -13

Ari Setiawan, Syarief Fajarudin, Dinar Westri Andini

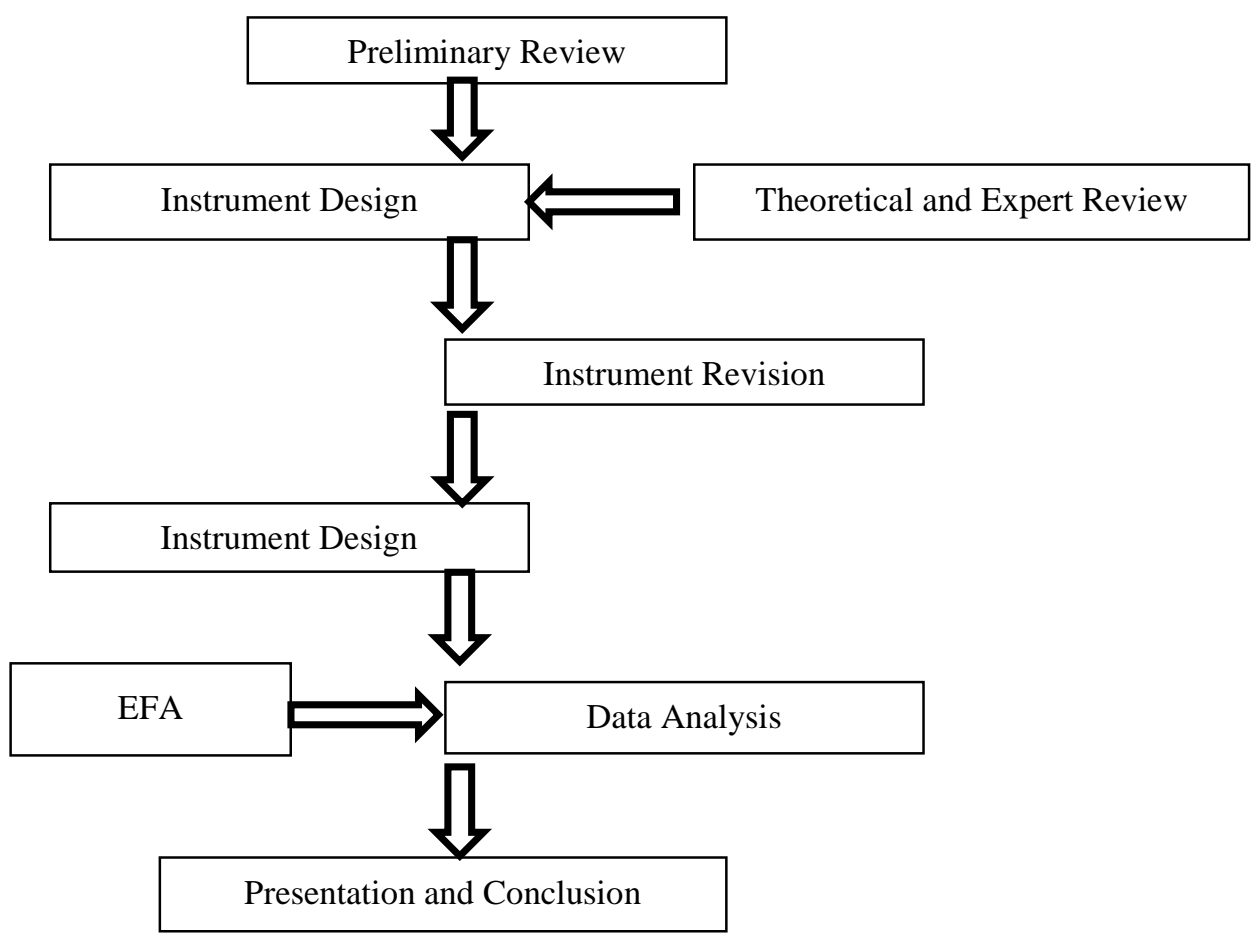

Figure 1. The Sequence for the Development of Honesty and Discipline Assessment Instrument

The second stage of validity test was meaningfulness path test. This stage was identical to the construct validity test. The meaningful path test was performed by testing the construct that had been proposed in the instrument of honesty and discipline assessment. After the meaningful path test analysis was performed, the indicators were converted into the items for the Self-Assessment (SA) instrument and the PeerAssessment (PA) instrument. The approach that had been adopted for the construct validity test was the Exploratory Factor Analysis (EFA). The use of the criteria was viewed in MSA with minimum requirement 0.50 . This loading factor served as the reference in making decisions on the valid items.

After the construct validity test had been completed, the next test that should be conducted was the reliability estimation test toward the social attitude assessment. The results of the reliability test showed how far consistency, continuity, stability and trustworthiness had been achieved in both the measurement results and the instrument of social attitude assessment so that the measurement results might be reliable; in other words, according to its concept reliability might be defined as how far measurement results might be trustworthy (Azwar, 2015). The reliability estimation test for the instrument of social attitude test among the elementary school students was performed by using the internal consistency approach with the support from the
Cronbach's Alpha formula and SPSS 20.00. The Cronbach's Alpha formula was used based on the dichotomous (non-interrogative) responses in the instrument. The criterion for defining the reliability of the instrument was as follows: if the Alpha coefficient is equal to 0.70 or higher then the instrument is reliavle (Mardapi, 2017; Nunnally \& Bernstein, 1994). The instrument that had been developed already had high index of reliability (minimum 0.70) and thus the instrument might be implemented in the test. An instrument that has high reliability index is very good for implementation because the instrument is more consistent in measurement.

The instrument reliability was very important because the instrument reliability displayed the stability and consistency within the implementation. A stable instrument might be employed to the respondents that had characteristics similar to the study. Consequently, the results of the assessment instrument that had been developed might be widely implemented.

Then, for the data analysis toward the results of honesty and discipline assessment the researchers employed categorization on the assessment results by using score, mean score and standard deviation. These data were attained from the overall score that had been gathered from the respondents. On the other hand, for the data that had been attained from the social attitude assessment instrument the researcher employed the categorization that had been 
proposed by Mardapi (2007). The categorization might be consulted in Table 1 below.

Table 1. Categorization of Honesty and Discipline

\begin{tabular}{ccc}
\hline No. & $\begin{array}{c}\text { Elementary School Students' } \\
\text { Score }\end{array}$ & Category \\
\hline 1. & $\mathrm{X} \geq \bar{X}+1 . \mathrm{SDx}$ & Internalized \\
2. & $\bar{X}+1 . \mathrm{SDx}>\mathrm{X} \geq \mathrm{X}$ & Developed \\
3. & $X>\mathrm{X} \geq X-1 . \mathrm{SDx}$ & Apparent \\
4. & $\mathrm{X}<X-1 . \mathrm{SDx}$ & Inapparent \\
\hline
\end{tabular}

Note:

$\bar{X}$ : overall mean score of the elementary students in a classroom

SDx: standard deviation for the overall score of the elementary school students in a classroom

$\mathrm{X}$ : score that the students had achieved

The categorization was assigned to each student in detail for the honesty and discipline assessment. The results of the categorization might display the tendency of the students' honesty and discipline.

\section{Results and Discussions}

Content Validity

The content validity test is performed by distributing the instrument to the experts for gathering the results of their qualitative assessment. This validation is performed in order to view whether the instrument that had been designed had good content validity or not. Within the process, the experts assess and give feedback on the draft of the instrument, the consistency between the guidelines and the choice of words and the continuity between the guidelines and the items of the instrument that has been developed. The results of the assessment toward the instrument are provided in numbers. The numbers then are estimated by using the Aiken formula in order to view how valid the indicators and the items that had been designed were. The results of the estimation by using the Aiken Formula might be viewed in Table 2.

From the results of content validity by using the Aiken Formula, it is found that the Aiken score for all items has been ranging from 0.750 until 1.000 which has been higher than 0.700 (> 0.700). The implication is that the indicators that has been proposed were valid (compatible) to the existing components. Table 2 shows that from 6 indicators 5 indicators belong to the "High" category and 1 category belongs to "Moderate" category. As a result, it might be concluded that all indicators that have been proposed might be implemented into the design of honesty and discipline assessment instrument for elementary school students.

The content validity is assessed in terms of items and the results of item reliability measurement are gathered from the compatibility between the items and the indicators that has been proposed. The estimation method that has been adopted is the Aiken Index. The results of Aiken Index calcilation for the PA instrument might be consulted in Table 2. From the results in Table 2, it is found that all items in the PA Instrument belong to the "Valid" category since the results of the Aiken Index that has been gathered range from 0.750 until 1.000. Because the results of Aiken Index have been higher than 0.700, all items in the instrument that has been developed already have good and feasible level of validity for the further conduct of the study. Then, the item dissemination consists of 18 items with 15 items belong to the "High" category and 3 items belong to the "Low" category.

The Aiken Index calculation involves several experts namely the measurement and assessment expert, the character education expert and the children's affective development expert. The results of Aiken Index calculation might be consulted in Table 3.

Table 2. The Results of Aiken Index for the Compatibility between the Indicators and the Components

\begin{tabular}{ccccc}
\hline No. & Components & Indicators & Aiken Index & Criteria \\
\hline 1. & Honesty & Indicator 1 & 0.833 & High \\
& & Indicator 2 & 0.917 & High \\
& & Indicator 3 & 0.750 & Moderate \\
2. & \multirow{2}{*}{ Discipline } & Indicator 1 & 1.000 & High \\
& & Indicator 2 & 1.000 & High \\
& & Indicator 3 & 0.917 & High \\
\hline
\end{tabular}


Jurnal Prima Edukasia, 7 (1), 2019 -15

Ari Setiawan, Syarief Fajarudin, Dinar Westri Andini

Table 3. The Results of Aiken Index for the Compatibility between the Items and the Indicators of PA Instrument

\begin{tabular}{lllcrc}
\hline No. & Component & \multicolumn{1}{c}{ Indicators } & Item & Aiken Index & Criteria \\
\hline 1. & Honesty & The students com-plete the test inde- & Item 1 & 1.000 & High \\
& pendently & Item 2 & 0.917 & High \\
& & Item 3 & 0.833 & High \\
& & Item 4 & 0.917 & High \\
& & The students deliver information in a & 0.750 & Moderate \\
& straightforward man-ner & Item 2 & 0.917 & High \\
& & Item 3 & 0.917 & High \\
& & Item 4 & 1.000 & High \\
& & Item 5 & 0.917 & High \\
& & Item 1 & 1.000 & High \\
2. & & Item 2 & 1.000 & High \\
& \multirow{4}{*}{ Discipline } & The students come on time to school / & 0.750 & Moderate \\
& classroom & Item 3 & 0.833 & High \\
& & Item 4 & 0.917 & High \\
& & Item 5 & 0.917 & High \\
& & Item 1 & 1.000 & High \\
& & Item 2 & 0.917 & High \\
& The students obey the school regulation & Item 3 & 0.750 & High
\end{tabular}

Table 4. The Results pf PA Instrument Readability

\begin{tabular}{clccc}
\hline No. & PSSA Instrument & Comprehension & User-Friendliness & Attraction \\
\hline 1. & Good & 10 & 9 & 11 \\
2. & Moderate & 3 & 3 & 3 \\
3. & Low & 2 & 3 & 1 \\
\hline
\end{tabular}

Instrument Readability Test

Based on the suggestion and the results of content validity (by means of Aiken Index), the researcher performs overall improvement toward the instrument. The improvement that has been performed aims at generating ready-to-implement instrument. Prior to the second implementation, the instrument that has been revised should be put into the readability test. The readability test is performed on the elementary school students by involving 15 respondents from these students. The results of the PA instrument readability test show that the students respond the PA instrument well. Furthermore, from 15 students 10 students have good understanding toward the instrument while 9 students have good response toward the instrument readability. In terms of attraction, 11 students show good response. These findings show that the PA instrument is feasible for implementation. A better description on these responses might be consulted in Table 4 and Figure 3.

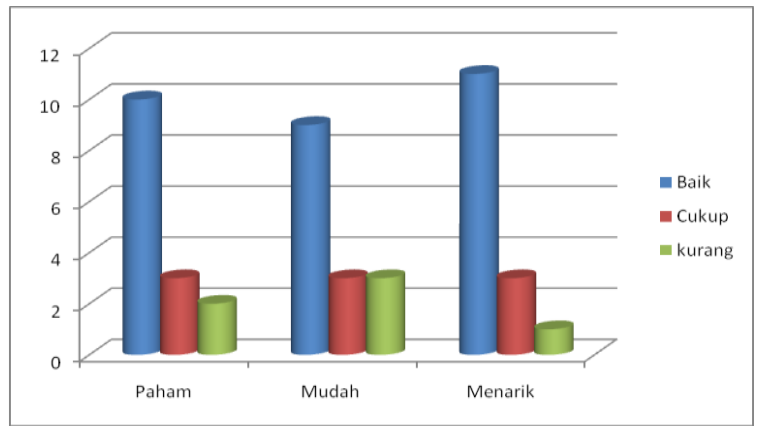

Figure 2. The Histogram of PA Instrument Readability Test

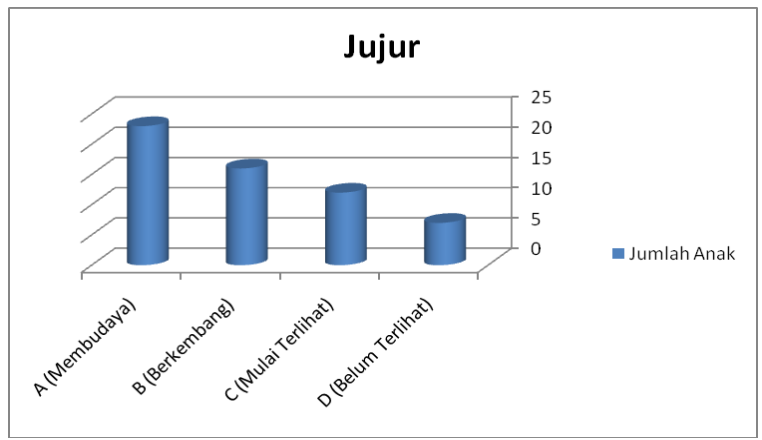

Figure 3. The Histogram of Students' Honesty Assessment 
Jurnal Prima Edukasia, 7 (1), 2019 -16

Ari Setiawan, Syarief Fajarudin, Dinar Westri Andini

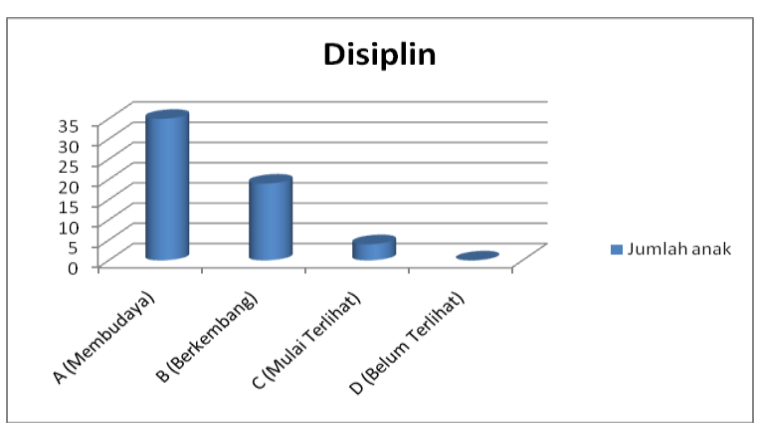

Figure 4. The Histogram of Students' Discipline Assessment

\section{Construct Validity and Reliability}

The analysis for the construct validity is performed by using the CFA approach. In the preliminary stage, the KMO Bartlett test is performed in order to identify the sample adequacy. The results of KMO Bartlett test show that the KMO Bartlett index is equal to 0.832 and the figure implies that the samples come from the population with the same variance. Then, in order to identify the item validity the researcher employs the anti-image correlations in which the results of EFA range between 0.500 and 0.900 . These results imply that the items in the instrument have been valid and applicable.

After viewing the Aiken Index, the researcher views the Eigenvalue in order to define the factors or the components that have been established. The results of the Eigenvalue might be consulted in Table 5 .

Table 5. The Results of Eigenvalue from the Instrument

\begin{tabular}{clc}
\hline No. & Komponen/Faktor & Eigen Value \\
\hline 1. & Component 1 & 7.562 \\
2. & Component 2 & 1.639 \\
3. & Component 3 & 1.517 \\
4. & Component 4 & 1.272 \\
\hline
\end{tabular}

From the results in Table 5, it is found that the instrument under analysis yields four components. These components are the ones that will be the indicators of honesty and discipline assessment instrument.

After the validity estimation test has been conducted, the researcher views the reliability value. The result of validity estimation test by means of Cronbach's Alpha is 0.832 . This value indicates that the instrument has already been reliable. Actually, the definition of both measurement reliability and measurement validity is similar. The only difference lies in the usage of the term. The concept of reliability in the measurement reliability has strong association to the error of measurement. The error of measure- ment itself displays how far the inconsistency within the measurement results will take place if repetitive measurement is conducted toward the same subject. One of the factors that might cause the error of measurement is the variation within the response of the respondents (Viswanathan, 2005); for example, there is an extreme response in which one item has been massively responded by the respondents. Departing from this explanation, high level of reliability implies low error of measurement and vice versa (Coaley, 2010). In relation to the situation, error of measurement should be given attention in order to attain an instrument with high level of reliability.

On the contrary, reliability refers to the correlation between the item scale and all responses toward the item within the instrument (Robinson, Shaver, Wrightsman \& Andrews, 1991). The concept of reliability deals with how far the results of measurement process might be trustworthy (Azwar, 2015). The reliability estimation test toward an instrument is performed by using a consistency approach namely the Cronbach's Alpha formula. The formula is not based on the interrogative type of instrument response but instead the formula is based on the gradual type of instrument response, which is elicited from the respondents' alternative criteria. An instrument will be considered reliable if the item joint coefficient (Alpha reliability) is equal to 0.70 or higher (Mardapi, 2017; Nunnally \& Bernstein, 1994; Sunyoto, 2012). Looking at the definition, it might be safely concluded that the instrument that has been developed is already reliable.

After the instrument that has been developed is considered valid, the instrument is implemented into the process of honesty and discipline assessment. The results of honesty assessment might be consulted in Table 6 below.

Table 6. The Score of Elementary School Students' Honesty

\begin{tabular}{clcc}
\hline No. & \multicolumn{1}{c}{ Score } & $\begin{array}{c}\text { Number of } \\
\text { Students }\end{array}$ & Percentage \\
\hline 1. & A (internalized) & 35 & $60.34 \%$ \\
2. & B (developed) & 19 & $32.76 \%$ \\
3. & C (apparent) & 4 & $6.90 \%$ \\
4. & D (inapparent) & 0 & $0.00 \%$ \\
& Total & 58 & $100.00 \%$ \\
\hline
\end{tabular}

From the results in Table 6, it is apparent that the elementary school students' honesty score falls to the "A (internalized)" category. However, the honesty score from some elementary school students falls to the "D (inapparent)." 
These scores imply that honesty as a social attitude has been starting to internalize within the thematic learning process. The results in this section might be consulted in Figure 3. Furthermore, the results in Table 6 and Figure 3 show that in general from 58 elementary school students 23 students $(39.66 \%)$ fall into the "A (internalized)" category, 16 students (27.58\%) fall into the "B (developed)" category, 12 students $(20.68 \%)$ fall into the "C (apparent)" category and 7 students (12.07\%) fall into the " $D$ (inapparent)" category.

In relation to school life, honesty might be defined as not committing any act of plagiarism (Koelhoffer, 2009). As a result, honesty might include not the work of a peer and admitting it as his or her work without any permission. In addition, honesty might be displayed by copying a peer's assignment, cheating during a test and paying someone to complete the homework. The honesty that has been manifested within the elementary school students will bring about huge contribution toward the students' affective development. The students who have internalized honesty in their daily life will gain success within their learning process.

After the honesty has been assessed, the researcher process to the assessment of discipline among the elementary school students. The results of the discipline assessment might be consulted in Table 7.

Table 7. The Results of the Elementary School Students' Discipline Assessment

\begin{tabular}{clcc}
\hline No. & \multicolumn{1}{c}{ Score } & $\begin{array}{c}\text { Number of } \\
\text { Students }\end{array}$ & Percentage \\
\hline 1. & A (internalized) & 23 & $39.66 \%$ \\
2. & B (developed) & 16 & $27.59 \%$ \\
3. & C (apparent) & 12 & $20.68 \%$ \\
4. & D (inapparent) & 7 & $12.07 \%$ \\
& Total & 58 & $100.00 \%$ \\
\hline
\end{tabular}

From the results in Table 7, it is clear that the elementary school students' discipline falls into the "A (internalized)" category. Then, the honesty score of the remaining students is fallen into the "B (developed)" category and the " $\mathrm{C}$ (apparent)" category. In other words, there are not any students whose discipline score falls into the "D (inapparent)" category. These scores imply that the elementary school students' discipline as a social attitude has been starting to internalize within the thematic learning process. The results in this section might be consulted in Figure 4. Furthermore, the results in Table 4 and Figure 4 show that in general from 58 students 35 students $(60.34 \%)$ fall into the "A (internalized)" category, 19 students $(32.76 \%)$ fall into the "B (developed)" category and 4 students (6.90\%) belong to the "C (apparent)" category.

Nucci \& Narvaez (2008, p.197) explains that developmental discipline can help teachers build the trusting relationships necessary for all students to learn and develop academically and morally. The development of discipline that has been pursued by the teachers is able to mould the students into a personality of discipline with increasing academic achievements. The students who have the characteristics of discipline in their daily life will also display their discipline when they attend the learning process not only in their house but also in their school so that the students will indirectly enjoy the increasing academic achievement. The high level of discipline among the elementary school students will trigger their success in their learning process. Internalizing discipline in the thematic learning process will certainly shape the culture of discipline among the elementary school students. In other words, it is certainly clear that the thematic learning approach that has been implemented is able to generate the personality of discipline among the elementary school students.

\section{Conclusions}

Based on the analysis toward and the discussion of the instrument of honesty and discipline assessment, the researcher would like to draw several conclusions. First of all, there are four components in the instrument of honesty and discipline assessment namely: (1) the students complete the test independently; (2) the students deliver information in a straightforward manner; (3) the students come on time to school/ classroom and (4) the students obey the school regulation (the first two components belong to the indicators of honesty while the latter two components belong to the indicators of discipline). Second, in terms of validity the instrument of honesty and discipline assessment that has been developed belongs to the "High" category and thus already meets the requirements of construct validity. Third, in terms of construct validity the instrument of honesty and discipline assessment that has been developed already meets the requirements of validity; therefore, all of the items within the instrument have already been valid. Fourth, in terms of reliability the instrument of honesty and discipline assessment that has been developed already meets the requirements of reliability; as a result, the instrument has 
Jurnal Prima Edukasia, 7 (1), 2019 -18

Ari Setiawan, Syarief Fajarudin, Dinar Westri Andini

been reliable. Fifth, due to meeting the requirements the instrument that has been developed might be implemented into the assessment process.

\section{References}

Ain, N., \& Rahutami, R. (2018). Theme network in thematic learning in elementary school. Journal of Physics: Conference Series, 1013(1), 012065 . https://doi.org/10.1088/17426596/1013/1/012065

Azwar, S. (2015). Reliabilitas dan validitas. Yogyakarta: Pustaka Pelajar.

Clarke, S. (2005). Formative assessment in action: weaving the elements together. London: Hodder Murray.

Coaley, K. (2010). An introduction to psychological assessment \& psychometrics. London: Sage Publications.

Crano, W. D., \& Prislin, R. (2008). Attitudes and attitude change. New York: Psychology Press.

Dochy, F., Segers, M., \& Sluijsmans, D. (1999). The use of self-, peer and co-assessment in higher education: A review. Studies in Higher Education, 24(3), 331-350. https://doi.org/10.1080/030750799123313 79935

Ekowarni, E. (2009). Pedoman pendidikan akhlak mulia siswa sekolah dasar. Jakarta: Departemen Pendidikan Nasional, Direktorat Pendidikan Dasar dan Menengah.

Ellington, H., Earl, S., \& Cowan, J. (1997). Making effective use of peer and self assessment. Aberdeen: The Robert Gordon University.

Handayani, I. R. (2018). Peran lingkungan sosial terhadap perilaku dan kedisiplinan anak usia sekolah dasar. Universitas Muhammadiyah Surakarta.

Handayani, M. (2018). Developing thematicintegrative learning module with problembased learning model for elementary school students. Jurnal Prima Edukasia, $6(2)$, 166-176. https://doi.org/10.21831/JPE.V6I2.14288

Karami, A., \& Rezaei, A. (2015). An overview of peer-assessment: The benefits and importance. Journal for the Study of
English Linguistics, 3(1), 93. https://doi.org/10.5296/jsel.v3i1.7889

Karli, H. (2016). Pembelajaran tematik untuk meningkatkan jiwa kewirausahaan siswa kelas 1-3 SD. EduHumaniora| Jurnal Pendidikan Dasar Kampus Cibiru, 3(2). https://doi.org/10.17509/eh.v3i2.2804

Koellhoffer, T. T. (2009). Character education being fair and honest. New York, N.Y.: Infobase Publishing.

Kumaidi, K. (2014). Validitas dan pemvalidasian instrumen penilaian karakter. In Seminar Psikometri Fakultas Psikologi Universitas Muhammadiyah Surakarta. Surakarta: Universitas Muhammadiyah Surakarta.

Lickona, T. (2004). Educating for character: how our schools can teach respect and responsibility. Nuw York: Bantam.

Mardapi, D. (2017). Pengukuran penilaian dan evaluasi pendidikan. Yogyakarta: Nuha Medika.

McCoach, D. B., Gable, R. K., \& Madura, J. P. (2013). Instrument development in the affective domain: School and corporate applications. Springer.

Meinbach, A. M., Rothlein, L., \& Fredericks, A. D. (2000). The complete guide to thematic units: Creating the integrated curriculum. Norwood, MA: Christopher-Gordon Publishers.

Millah, D., \& Syah, M. N. S. (2017). The implementation of integrative thematic learning in class I of State Elementary School 2 Barongan Kudus. ELEMENTARY: Islamic Teacher Journal, 5(2), 251-277. https://doi.org/10.21043/ELEMENTARY. V5I2.2989

Mujimin, M. (2006). Implementasi pembelajaran tematik bagi anak berkelainan. JKP (Jurnal Pendidikan Khusus), 2(2). Retrieved from https://journal.uny.ac.id/index.php/jpk/arti cle/view/983

Nucci, L. P., \& Narváez, D. (2008). Handbook of moral and character education. Routledge.

Nunnally, J. C., \& Bernstein, I. H. (1994). Psychometric theory (McGraw-Hill series in psychology). New York, N.Y.: McGraw-Hill. 
Raka, G., Mulyana, Y., Markam, S. S., Semiawan, C. R., Hasan, S. H., Bastaman, H. D., \& Nurachman, N. (2011). Pendidikan karakter di sekolah: Dari gagasan ke tindakan. Jakarta: PT Gramedia.

Retnawati, H. (2016). Proving content validity of self-regulated learning scale (The comparison of Aiken index and expanded Gregory index), 2(2). https://doi.org/10.21831/reid.v2i2.11029

Robinson, J. P., Shaver, P. R., Wrightsman, L. S., \& Andrews, F. M. (1991). Measures of personality and social psychological attitudes. Academic Press.

Salamah, U. (2017). Model pembelajaran tematik pendidikan agama Islam di sekolah dasar. Jurnal Pendidikan Agama Islam, 11(1), 119-132.

https://doi.org/10.14421/jpai.2014.111-08

Setiawan, A., \& Suardiman, S. P. (2018). Assessment of the social attitude of primary school students. REiD (Research and Evaluation in Education), 4(1), 12-21. https://doi.org/10.21831/reid.v4i1.19284

Soero, P. M. H. P., Sulistyo, D., \& Hayat, A. (2014). Pemberdayaan istri nelayan melalui koperasi unit desa (KUD) (Studi pada KUD Mina Jaya Sendang Biru Kecamatan Sumbermanjing Wetan Kabupaten Malang). Jurnal Administrasi Publik, 2(1), 41-46. Retrieved from http://administrasipublik.studentjournal.u b.ac.id/index.php/jap/article/view/337

Sriyati, S., Permana, A., Arini, A., \& Purnamasari, M. (2016). Efektivitas peer assessment dalam menilai kemampuan kinerja siswa pada kegiatan praktikum biologi. Proceeding Biology Education Conference: Biology, Science, Enviromental, and Learning, 13(1), 372376. Retrieved from https://jurnal.uns.ac.id/prosbi/article/view/ 5752

Stiggins, R. J. (2005). High quality classroom assessment: What does it really mean? Educational Measurement: Issues and Practice, 11(2), 35-39. https://doi.org/10.1111/j.17453992.1992.tb00241.x

Sunyoto, D. (2012). Validitas dan reabilitas dilengkapi analisis data dalam penelitian kesehatan. Yogyakarta: Nuha Medika.

Utari, U., Degeng, I. N. S., \& Akbar, S. (2016). Pembelajaran tematik berbasis kearifan lokal di sekolah dasar dalam menghadapi Masyarakat Ekonomi ASEAN (MEA). Jurnal Teori Dan Praksis Pembelajaran IPS, 1(1), 39-44. https://doi.org/10.17977/JTP2IPS.V1I1.58 61

Viswanathan, M. (2005). Measurement error and research design. Sage Publications. Retrieved from https://uk.sagepub.com/en$\mathrm{gb} / \mathrm{asi} / \mathrm{measurement-error-and-research-}$ design/book226938

Wanner, T., \& Palmer, E. (2018). Formative selfand peer assessment for improved student learning: the crucial factors of design, teacher participation and feedback. Assessment \& Evaluation in Higher Education, 43(7), 1032-1047. https://doi.org/10.1080/02602938.2018.14 27698

Widyaningrum, R. (2012). Model pembelajaran tematik di MI/SD. Cendekia: Jurnal Kependidikan Dan Kemasyarakatan, 10(1), 107-120.

Wijayanti, E., \& Mundilarto, M. (2015). Pengembangan instrumen asesmen diri dan teman sejawat kompetensi bidang studi pada mahasiswa. Jurnal Penelitian Dan Evaluasi Pendidikan, 19(2), 129-144. https://doi.org/10.21831/pep.v19i2.5572. 